\title{
Peran Humas Pemerintah Daerah dalam Kasus Penambangan Pasir Besi
}

\author{
Harry Broto Widodo, Siti Fatonah, Retno Hendariningrum \\ Program Studi Ilmu Komunikasi Fakultas Ilmu Sosial Ilmu Politik \\ Universitas Pembangunan Nasional "Veteran" Yogyakarta \\ J1. Babarsari No. 2 Tambakbayan Yogyakarta 55282, Telp. (0274) 485268 \\ Telp: 085228529964/email: harry_widodo@yahoo.com
}

\begin{abstract}
This research entitles "The Role Of The Public Relations Of Kulon Progo Local Government (In the Case of Iron Sand Mining in Kulon Progo Regency)." Today, Kulon Progo Regency still face the pro and con problems regarding iron sand mining. The government of Kulon Progo Regency is required to be able to build communication with all parties in solving the problems. This research is aimed at identifying the implementation of public relations role of the government of Kulon Progo Regency in facing iron sand mining case problems in Kulon Progo Regency as well as obstacles faced by the government of Kulon Progo Regency in enacting the role of public relations in dealing with the problems. This research employs qualitative descriptive analysis. The activity of qualitative descriptive analysis is done by processing the data obtained through interview, observation and documentation technique. Based on research results, it is concluded that although Public relations have done its role in the plan socialization of iron sand mining in Kulon Progo Regency, but the false perception held by the society about mining process has not changed yet, it means that the Power Control Theory which is conducted by the Public Relations of Kulon Progo Local Government is not maximum yet. The obstacles faced by the Public Relations of Kulon Progo Local Government in dealing with iron sand mining problems in Kulon Progo are first, internal obstacles in the function of public relations which has the position as the dominant coalition in relation to its authority in entering social responsibility, public understanding or two-way communication is not maximum yet, second, a false perception held by the people of southern sea shore upon the process of mining process Keywords: Public relations role; Government of Kulon Progo Regency; Power Control Theory
\end{abstract}

\begin{abstract}
Abstrak
Penelitian ini memberikan judul "Peran Humas Pemkab Kulon Progo (Dalam Kasus Penambangan Pasir Besi di Kabupaten Kulon Progo)." Saat ini, Kabupaten Kulon Progo masih menghadapi masalah pro dan kontra terkait penambangan pasir besi. Pemerintah Kabupaten Kulon Progo dituntut untuk dapat membangun komunikasi dengan semua pihak dalam menyelesaikan masalah tersebut. Penelitian ini bertujuan untuk mengidentifikasi pelaksanaan peran Humas Pemerintah Kabupaten Kulon Progo dalam menghadapi permasalahan kasus penambangan pasir besi di Kabupaten Kulon Progo serta kendala yang dihadapi pemerintah Kabupaten Kulon Progo dalam memberlakukan peran humas dalam menangani masalah tersebut. Penelitian ini menggunakan analisis deskriptif kualitatif. Kegiatan analisis deskriptif kualitatif dilakukan dengan memproses data yang diperoleh melalui teknik wawancara, observasi dan dokumentasi. Berdasarkan hasil penelitian, disimpulkan bahwa meskipun Humas telah melakukan perannya dalam rencana sosialisasi penambangan pasir besi di Kabupaten Kulon Progo, namun persepsi keliru yang dimiliki masyarakat tentang proses penambangan belum berubah, artinya Power Control Theory yang dilakukan oleh Humas Pemkab Kulon Progo belum maksimal. Kendala yang dihadapi Humas Pemkab Kulon Progo dalam menangani masalah penambangan pasir besi di Kulon Progo adalah pertama, kendala internal dalam fungsi humas yang memiliki posisi sebagai koalisi dominan dalam kaitannya dengan kewenangannya dalam memasuki tanggung jawab sosial, pemahaman masyarakat atau komunikasi dua arah belum maksimal, kedua, kesalahan persepsi oleh masyarakat pesisir selatan terkait proses-proses penambangan. Kata kunci: Peran humas; Pemerintah Kabupaten Kulon Progo; Power Control Theory
\end{abstract}




\section{Pendahuluan}

Dalam melaksanakan tugasnya humas pemerintah tidak dapat dipisahkan dari opini publik, terutama dalam bidang pemerintahan yang langsung atau tidak langsung mempunyai hubungan dengan berbagai publik dan mengatur kesejahteraan dan keamanan tiap warga negaranya. Tiap kegiatan pemerintah di negara demokratis, banyak tergantung dari bantuan publik, pemerintah akan mendapat tentangan-tentangan bila kepentingan publik tidak diperhatikan dan jika mereka tidak mendapatkan informasiinformasi tentang peraturan, rencana dan kegiatankegiatan lainnya (Abdurrachman, 2001: 113).

Kabupaten Kulon Progo saat sekarang masih dihadapkan pada permasalahan pro dan kontra penambangan pasir besi. Pemerintah Kabupaten Kulon Progo dituntut mampu menjalin komunikasi dengan semua pihak guna menyelesaikan permasalahan tersebut. Komunikasi yang baik antara pemerintah Kabupaten dengan masyarakat, perusahaan maupun investor sangat dibutuhkan agar tercapai penyelesaian yang adil dan menguntungkan bagi semua pihak. Dalam konteks inilah, pemerintah Kabupaten Kulon Progo harus memainkan peran humas sebaik-baiknya agar permasalahan penambangan pasir tidak berlarut-larut.

Kegiatan penambangan pasir besi masuk ke salah satu kegiatan eksplorasi sumber daya mineral, batubara, dan sumber daya geologi lainnya. Bergantung pada banyak hal seperti permintaan pasar, harga di pasar internasional, kondisi geologi negara tersebut, perkembangan teknologi, modal, dan lain sebagainya (Islah, 2010). Penambangan pasir besi merupakan usaha di bidang pertambangan yang dimaksudkan untuk mengambil, mengolah dan memanfaatkan pasir besi agar bernilai ekonomi lebih tinggi seperti yang sedang dirintis di Kabupaten Kulon Progo. Upaya membuka industri pasir besi di Kabupaten Kulon Progo pada dasarnya adalah langkah maju untuk meningkatkan kesejahteraan rakyatnya. Niat baik ini sudah seharusnya dikomunikasikan dengan baik kepada masyarakat, khususnya masyarakat yang langsung terkena dampak penambangan, baik dampak positif ataupun negatif. Komunikasi ini diharapkan dapat menumbuhkan partisipasi dan dukungan masyarakat terhadap penambangan pasir besi. Pada kenyataannya, penambangan pasir besi di Kabupaten Kulon Progo telah menimbulkan kontroversi di tengah masyarakat.

Konsultasi publik terkait penyusunan Analisis Mengenai Dampak Lingkungan (Amdal) yang digelar perusahaan pemrakarsa penambangan pasir besi PT Jogja Magasa Iron (JMI) di gedung kaca pemerintah kabupaten Kulon Progo diwarnai bentrokan antara petugas keamanan dengan warga Panguyuban Petani Lahan Pantai (PPLP). Akibatnya 5 warga PPLP mengalami luka berat dan puluhan luka ringan. Lima warga dilarikan ke rumah sakit. Konsultasi publik dari awal berlangsung panas. Sejumlah pengurus dan warga PPLP di antaranya Ketua PPLP Supriyadi, Koordinator lapangan (Korlap) Widodo berusaha masuk ke ruang konsultasi publik. Namun oleh penerima tamu Kepala Lingkungan Hidup (KLH) Djunianto Marsudi Utomo tidak memperbolehkan, karena nama mereka tidak tercantum dalam daftar undangan.

Di pihak lain pengurus dan warga PPLP memaksakan diri ingin masuk karena undangan mereka resmi diberikan Pemkab Kulon Progo. Namun setelah terjadi dialog antara pengurus PPLP dengan pihak Pemkab akhirnya beberapa pengurus PPLP didampingi personel LBH Yogya diijinkan masuk untuk mengikuti konsultasi publik yang dihadiri Wabup Kulon Progo Mulyono, GKR Pembayun, GPBH Joyokusumo dan pimpinan PT. Jogja Magasa Iron. Pada saat konsultasi publik yang semula tertib, tiba-tiba perwakilan PPLP minta waktu untuk membacakan pernyataan sikap. Perwakilan PPLP juga meminta Pemkab dan PT JMI menemui pengunjuk rasa. Perwakilan warga kemudian meninggalkan ruangan dan bergabung dengan pengunjuk rasa di luar pagar. Tak selang lama pendemo merangsek mendekati barikade polisi, sehingga terjadi saling 
dorong disusul saling pukul dan hujan batu. Bentrokan dipicu kekecewaan massa atas tidak dipenuhinya keinginan agar Pemkab Kulon Progo dan PT JMI (Jogja Magasa Iron) menemui warga PPLP untuk menjelaskan rencana penambangan pasir besi. (Kedaulatan Rakyat, 21 oktober 2009).

\section{Public Relations}

Menurut The International Public Relations Associations (dalam Kurniasari dkk, 2008), Public Relations atau Hubungan Masyarakat (Humas) adalah fungsi manajemen dari hal yang dijalankan secara berkesinambungan dan berencana, yang mana organisasi-organisasi dan lembaga-lembaga yang bersifat umum dan pribadi berusaha memperoleh dan membina pengertian, simpati dan dukungan dari mereka yang ada sangkut pautnya atau yang mungkin ada sangkut pautnya - dengan menilai pendapat umum di antara mereka dengan tujuan sedapat mungkin menghubungkan kebijaksaan dan ketatalaksanaan mereka, guna mencapai kerja sama yang lebih produktif dan untuk melaksanakan kepentingan bersama yang lebih efisien, dengan melancarkan informasi yang berencana dan tersebar luas.

Sedangkan The British Institute of Public Relations yang dilansirEffendy (dalam Kurniasari dkk, 2008) mendefinisikan humas sebagai upaya yang mantap, berencana dan berkesinambungan untuk menciptakan dan membina pengertian bersama antara organisasi dengan khalayak.

\section{Strategic Choice Theory dan Power Control Theory}

Kerangka pemikiran Grunig dkk mempertegas dua teori yang dikemukakan dua dekade sebelumnya yaitu strategic choice theory (Child, 1972) dan power control theory (Burrey and Morgan, 1979). Child berpendapat bahwa efektivitas public relations menekankan pentingnya persepsi manajemen dan tindakan mereka untuk membentuk lingkungan dan mengarahkan struktur serta posisi public relations dalam organisasi.
Menurut Grunig, praktisi PR biasanya tidak mempunyai kebebasan untuk bertindak sebagai seorang profesional, kecualijika dia duduk sebagai bagian dari koalisi yang dominan. Jika unit PR menjadi bagian koalisi yang dominan, mereka mempunyai wewenang untuk memasukkan unsur tanggung jawab sosial, pemahaman publik atau komunikasi dua arah. Dengan cara ini akan lebih mudah dapat dilihat kontribusi PR terhadap efektivitas organisasi. Jika tujuan PR dimasukkan menjadi tujuan organisasi, esekutif PR duduk sebagai koalisi yang dominan. Sasaran program PR akan lebih dapat diadaptasikan jika esekutif PR merupakan koalisi yang dominan dalam organisasi. (Ridwan, 3: 2004).

\section{Metode Penelitian}

Penulis menggunakan jenis metode kualitatif untuk digunakan karena lebih berdasarkan pada filsafat fenomenologis yang mengutamakan penghayatan (verstehen). Metode kualitatif berusaha memahami dan menafsirkan makna suatu peristiwa interaksi tingkat laku manusia dalam situasi tertentu menurut perspektif peneliti sendiri. (Usman dan Akbar, 2009:78).

Fungsi public relations di Pemerintah Kabupaten Kulon Progo dijelaskan dengan pemaparan deskriptif. Pemaparan deskriptif ini sebatas menggambarkan sejelasnya situasi atau peristiwa, kejadian atau kejadian-kejadian selama penelitian dilakukan (Usman dan Akbar, 2009:130). Hal ini bertujuan untuk mengetahui pelaksanaan peran humas pemerintah Kabupaten Kulon Progo dalam menghadapi masalah kasus penambangan pasir besi di Kabupaten Kulon Progo dan Untuk mengetahui hambatanhambatan yang dihadapi pemerintah Kabupaten Kulon Progo dalam menjalankan peran humas dalam menghadapi masalah kasus penambangan pasir besi. Bidang Humas Pemerintah Kabupaten Kulonprogo,ProvinsiDaerahIstimewaYogyakarta dan di kecamatan di mana lokasi pertambangan berada menjadi sumber data yang utama. Data yang digunakan data primer dan data sekunder. 
Teknik pengumpulan data yang dilakukan dengan cara wawancara dan dokumentasi Untuk mengembangkan validitas data dilakukan dengan menggunakan teknik triangulasi data, yaitu suatu teknik pemeriksaan keabsahan data yang memanfaatkan sesuatu yang lain di luar data itu. Sesuatu dari luar data maksudnya adalah data yang didapat dari sumber, penyidikan, berdasar teori tertentu dan metode tertentu. (Moleong, 2007: 330). Triangulasi yang dipilih adalah triangulasi sumber sehingga dapat menguji keabsahan data dilakukan hanya dengan membandingkan data dari satu sumber dengan sumber yang lainnya. Sumber yang dapat digunakan antara lain wawancara dan observasi, dokumen tertulis, arsip, dokumen sejarah, catatan resmi, gambar atau foto. Pandangan yang beragam dapat menunjukkan kebenaran yang handal (Rahardjo, 2010).

Penulis menggunakan teknik mengontrol data yang sama dengan sumber data yang berbedauntuk mengurangi subyektivitas dalam penganalisaan terhadap data yang diperoleh. Teknik triangulasi yang digunakan dengan trianggulasi sumber, yaitu dengan cara membandingkan hasil wawancara dengan narasumber (Kepala sub bagian Humas Pemerintah Daerah Kabupaten Kulon Progo Ibu Arning Rahayu, Kepala sub bagian pertambangan Dinas Perindustrian Perdagangan dan ESDM (Energi Sumber Daya Mineral) Bapak Mustafa Ali Mochammad, Kepala kantor Kesbanglinmas (Kesatuan Bangsa dan Lindungan Masyarakat) Kabupaten Kulon Progo Bapak Marsudi Adji jabatan Kepala Seksi Kesatuan Bangsa, Kepala Desa Banaran Kecamatan Galur Kulon Progo dan Bapak Dwi haryanto, Kepala Badan Permusyawaratan Desa (BPD) Desa Banaran Kecamatan Galur Kulon Progo Bapak Sumitro, Kepala Desa Bugel Kecamatan Panjatan Kulon Progo Bapak Edi priyono, Kepala Badan Permusyawaratan Desa (BPD) desa Bugel Kecamatan Panjatan Kulon Progo Bapak Suprayitno, Tokoh masyarakat Desa Pleret pedukuhan 11 Kecamatan Panjatan Bapak
Sunarna) dan kajian terhadap suatu dokumen yang berkaitan dengan suatu penelitian. Keberadaan data yang satu akan dikonfirmasikan dengan data yang diperoleh dari sumber data yang lain, sehingga dianggap valid, oleh karena itu perlu dilakukan reduksi agar data yang dianalisis benarbenar memiliki validitas dan variabel yang tinggi.

Teknik yang digunakan sebagai teknik analisis data adalah model interaktif models of analysis atau analisis interaktif (Matthew B \&, Michael Huberman, 1992) yaitu bergerak diantara tiga komponen data, yaitu reduksi data, penyajian data dan penarikan kesimpulan. Aktifitas ketiga komponen tersebut bukanlah linear, namun lebih merupakan siklus dalam struktur kerja interaktif.

Analisis kualitatif deskriptif digunakan untuk menganalisis data kualitatif dengan mengolah data-data yang dikumpulkan melalui teknik wawancara, pengamatan dan dokumentasi. Setelah data selesai dikumpulkan dengan lengkap, maka tahap berikutnya adalah menganalisis data. Analisis data dimulai dengan menelaah seluruh data yang tersedia dari berbagai sumber. Selanjutnya dilakukan reduksi data yang dilakukan dengan jalan melakukan abstraksi. Abstraksi merupakan usaha membuat rangkuman yang inti, proses, dan pernyataan-pernyataan yang perlu dijaga sehingga tetap berada di dalamnya. Tahap selanjutnya adalah menyusun data tersebut ke dalam satuan-satuan tertentu untuk dikategorikan pada langkah berikutnya. Tahap berikutnya adalah mengadakan pemeriksaan keabsahan data (Moleong, 2007:247).

\section{Hasil Penelitian dan Pembahasan}

Keterbukaan pemerintah daerah Kulon Progo ini ditanggapi oleh PT Jogja Magasa Mining yang merupakan perusahaan patungan dengan Indo Mines Limited (perusahaan asal Australia) dengan membentuk perusahaan baru bernama PT Jogja Magasa Iron (JMI) yang mengajukan penawaran untuk berinvestasi dalam kegiatan penambangan pasir besi di Kulon Progo. Dengan adanya investasi diharapkan dapat mengurangi 
pengangguran, meningkatkan pertumbuhan ekonomi dan pada akhirnya meningkatkan kesejahteraan masyarakat. Penawaran ini disambut positif oleh pemerintah daerah dengan mengadakan kontrak karya. Berdasarkan prediksi, bila proyek penambangan pasir besi berhasil maka Indonesia dapat mengurangi impor bahan baku baja lebih dari $50 \%$. (sumber data instansi pertambangan Pemda Kulon Progo).

Harapan pemerintah, kegiatan penambangan pasir besi di Kulon Progo dapat mengurangi pengangguran, karena kegiatan penambangan dan pengolahan pasir besi akan menyerap lebih dari 2000 tenaga kerja. Hal ini akan berdampak positif terhadap peningkatan pertumbuhan ekonomi karena dapat menumbuhkan pendapatan masyarakat pekerja, kesempatan kerja dan usaha penduduk, royalti hasil tambang pajak-pajak, yang pada akhirnya meningkatkan pendapatan asli daerah. (sumber data instansi pertambangan Pemda Kulon Progo).

Kesepakatan Pemda Kulon Progo dan PT.JMI ini terwujud melalui penandatanganan kontak karya (KK) antar pemerintah Republik Indonesia dan PT. Jogja Magasa Iron pada tanggal 4 november 2008. Dalam salah satu isi kesepakatan, disepakati bahwa 30\% saham PT.JMI dimiliki oleh PT. Jogja Magasa Mining dan 70\% dimiliki oleh perusahaan asal Australia bernama Indo Mines Limited perusahaan patungan ini akan melakukan operasi dengan sistem tambang terbuka. Dengan estimasi cadangan besi yang terdapat dalam pasir besi sebesar 33,6 juta ton Fe (besi) dengan produksi sekitar 1 juta ton per tahun dengan masa operasi sekitar 30 tahun. Operasi penambangan ini akan mencakup luas wilayah 2.987, 79 Ha wilayah kontrak karya di kawasan pesisir pantai selatan. Jika sesuai dengan rencana, setelah penyetujuan Analisis Mengenai Dampak Lingkungan (AMDAL) proses penambangan dimulai pada tahun 2011 dan mulai memproduksi pada tahun 2012. Pada tahap konstruksi perusahaan akan menyerap tenaga kerja lokal sebanyak 5000 orang dan pada tahap awal produksi akan memperkerjakan tenaga kerja lokal sebanyak 3000 orang (sumber data instansi pertambangan Pemda Kulon Progo).

Berdasarkan siaran terbuka saat penandatanganan Kontrak Karya (KK) pada 4 november 2008, Robert A John Kepala Biro Hukum dan Humas Kepala Bagian Penelaahan Hukum, Departemen Energi dan Sumber Daya Mineral (ESDM), menyampaikan bahwa total investasi sebesar USD 1,1 milyar. Bila Dijabarkan antara lain berupa stock pile USD 5 juta, pemasangan rel (rail sliding) USD 6 juta, pembangkit listrik 350 MW senilai USD 350 juta dan fasilitas pelabuhan USD 10 juta dan investasi pertambangan sebesar USD 600 juta. Diharapkan proyek penambangan pasir besi di kabupaten Kulon Progo akan menyumbang penerimaan negara dari sisi pajak sekitar USD 20 juta/tahun, royalty sebesar USD 11,25 juta/ tahun, pendanaan lokal USD 7 juta/tahun dan operating expenditure (biaya operasional) USD 55 juta /tahun.

Pada dasawarsa pertama PT.JMI berjanji mengalokasikan $11,5 \%$ dari gross profit untuk community development. Pada 10 tahun pertama akan memberikan kontribusi ke daerah (Kabupaten) sebesar 1,5\% dari penjualan masing-masing untuk Regional Development dan Community Development dan setelah 10 tahun meningkat menjadi sebesar 2\% (http:// ginanjardimasagung.wordpress.com/2009/05/04/ menilik-pasir-besi-kulon-progo-pasirbesi-sebuah-anugerah-atau-bencana).

Sebelum masuk ketahap konstruksi dan produksi perusahaan PT JMI saat ini dalam tahap studi kelayakan lingkungan wilayah kontrak karya sesuai dengan Kep.Men ESDM NO.289.K/30/DJB/2009 tertanggal 27 April 2009 tentang Permulaan Tahap Studi Kelayakan Lingkungan (sumber data instansi pertambangan Pemda Kulonprogo).

Sehubungan dengan rencana penambangan pasir besi besi tersebut, Humas Pemkab Kulon Progo serta pihak yang terkait (PT JMI) dan instansi terkait di lingkungan Pemkab Kulon 
Progo) telah melakukan sosialisasi pada tahap pertama. Sosialisasi dilakukan melalui surat edaran atau pemberitahuan dari pemerintah kabupaten dalam hal ini kantor Lingkungan Hidup Pemkab Kulon Progo. Surat edaran tersebut diserahkan melalui pemerintah desa, kemudian pemerintah desa menyampaikan informasi tersebut kepada masyarakat, khususnya masyarakat yang terkena dampak langsung penambangan pasir besi di pesisir pantai Kulon Progo. Informasi tersebut ditindaklanjuti juga dengan undangan atau pemberitahuan kepada masyarakat terkait saat akan dilaksanakan pengambilan sampel. Dengan demikian masyarakat telah mengetahui dan menyetujui sebelum petugas dari PT JMI terjun ke lokasi bakal penambangan untuk mengambil sampel.

Sosialisasi tahap pertama dilanjutkan dengan sosialisasi tahap kedua yakni saat pengambilan sampel biji besi. Setelah diambil sampel biji besi diketahui bahwa kandungan biji besinya memungkinkan untuk ditambang. Pengambilan sampel ini merupakan sosialisasi tahap kedua. Pada tahap inilah terjadi penolakan oleh sebagian warga masyarakat yang tidak menyetujui rencana penambangan pasir besi.

Penambangan pasir besi di Kabupaten Kulon Progo pada prinsipnya bertujuan untuk menggali serta memaksimalkan potensi sumber daya alam, diharapkan dengan tergalinya sumber daya alam tersebut dapat memaksimalkan pendapatan daerah sehingga dapat meningkatkan kemakmuran dan kesejahteraan masyarakat daerah tersebut.

Pada kenyataannya, rencana penambangan pasir besi menimbulkan pro dan kontra pada masyarakat bahkan sudah mengarah ke konflik yang tentu saja merugikan semua pihak. Warga masyarakat pesisir selatan, terutama masyarakat sekitar penambangan pasir besi menganggap bahwa hadirnya operasi penambangan pasir PT Jogja Magasa Iron akan menghilangkan sumber mata pecaharian sebagai petani penggarap lahan pesisir pantai selatan, merusak tatanan sosial dan kebudayaan masyarakat pesisir pantai selatan, kerusakan lingkungan di kawasan penambangan pasir di pesisir pantai selatan dan permasalahan terkait hak atas lahan pantai dan kompensasi.

Pemerintah daerah melalui Humasnya telah memberikan informasi yang cukup memadai sehubungan dengan proses penambangan tersebut, sehingga diharapkan masyarakat dapat memperoleh informasi yang jelas mengenai dampak positif maupun negatif akibat proses penambangan tersebut.

Sosialisasi juga dilakukan dengan tatap muka dengan masyarakat pesisir pantai selatan Kulon Progo melalui media elektronik menggunakan LCD, brosur dan majalah mengenai teknis pelaksanaan penambangan. Gambar-gambar waktu pengambilan sampel, cara pengeboran serta masalah lingkungan hidup disekitar yang akan ditanami pohon cemara sebagai penahan angin atapun kabut dari pantai juga dipampangkan disekitar lokasi penambangan pasir besi. Diharapkan melalui cara ini masyarakat dapat mengetahui proses penambangan sehingga tidak salah persepsi terhadap kegiatan penambangan. Sosialisasi juga meliputi informasi mengenai teknis penambangan, ada beberapa alternatif yang akan dilakukan sebelum proses penambangan, yakni dibuat tanggul (berupa gundukan pasir) di sebelah selatan batas penambangan yang paling selatan dan ditanami cemara udang. Tiap lebar 200 meter panjang 1 kilo akan dilaksanakan penambangan tahap pertama. Jika proses ini telah selesai ditambang direklamasi kembali untuk lahan pertanian. Terhadap proses ini petani mendapat ganti untung dan uang tunggu yakni masa menunggu selama lahan tersebut diambil biji besinya. Adapun lahan yang dipergunakan penambangan pasir besi besarnya kompensasi $\mathrm{Rp}$ $20.000,-/ \mathrm{m}^{2}$ (20 ribu rupiah per meter persegi).

Penambangan pasir besi di Kabupaten Kulon Progo menimbulkan pro dan kontra dari berbagai elemen masyarakat. Masyarakat yang mendukung penambangan pasir besi di Kabupaten Kulon Progo berharap dengan adanya penambangan 
pasir besi kesempatan kerja, peningkatan ekonomi dan kesejahteraan masyarakat dapat tercapai.

Dari enam desa (Desa Banaran, Desa karangsewu, Desa Bugel, Desa Pleret, Desa Garongan dan Desa Karangwuni) hanya satu desa yakni Desa Banaran yang menerima keberadaan perusahaan penambangan pasir besi PT. Jogja Magasa Iron. Sebelumnya sudah disosialisasikan oleh Humas bekerjasama dengan instansi dinas perindustrian perdagangan dan ESDM Pemda Kabupaten Kulonprogo perihal rencana penambangan pasir besi di pesisir pantai selatan. Di desa Banaran lahan pesisir pantai selatannya dipakai untuk Pilot project (proyek percontohan) penambangan pasir besi dan masyarakat pantai selatandapatmelihatlangsungproyekpercontohan penambangan pasir besi yang sudah berjalan.

Tiga desa yang tetap menolak sosialisasi penambangan pasir besi yakni Desa Bugel, Desa Pleret dan Desa Garongan karena pemahaman masyarakat yang belum memadai tentang rencana penambangan dan pemrosesan pasir dan adanya bias pemahaman terhadap pertambangan seperti merusak lingkungan pesisir pantai selatan, penggusuran lahan pertanian yang berada di pantai, serta kekhawatiran masyarakat akan terjadinya bencana alam.

Adapun bentuk-bentuk sosialisasi humas beserta instansi jajarannya sehubungan dengan sosialisasi rencana penambangan pasir besi di Kabupaten Kulon Progo dalam rangka menjalankan perannya, adalah sebagai berikut : (1) penyuluhan yaitu kegiatan ini dilakukan oleh humas pemda terhadap para guru di lingkungan Kabupaten Kulon Progo. Materi yang disampaikan dalam penyuluhan ini berupa pengetahuan mengenai kegiatan pertambangan, termasuk proses penambangan, serta dampak yang ditimbulkannya. Dalam penyuluhan ini disampaikan bahwa penambangan pasir besi tidak mengakibatkan kerusakan yang serius terhadap lingkungan, namun sebaliknya dengan adanya penambangan pasir besi dapat menyerap tenaga kerja dalam jumlah yang banyak, dengan demikian dapat menjawab permasalahan pengangguran di daerah tersebut. Diharapkan melalui mekanisme penyuluhan terhadap guru-guru ini, penyampaian pesan akan lebih efektif, karena peranan sosial guru dalam masyarakat; (2) konsultasi publik yaitu konsultasi publik dilakukan dengan tatap muka secara langsung antara instansi yang berkepentingan dengan masyarakat sekitar lokasi penambangan dengan mekanisme tanya jawab.

Konsultasi Publik Rencana Kegiatan Pertambangan Pasir Besi dan Pemrosesan Pasir Besi diselenggarakan oleh Pemerintah Daerah Kabupaten Kulonprogro pada tanggal 20 Oktober 2009 di Gedung Kaca Pemerintah Daerah Kulonprogo. Konsultasi publik ini merupakan implementasi dari Peraturan Pemerintah Nomor 27 Tahun 1999 Tentang Analisis Mengenai Dampak Lingkungan (AMDAL) dan Keputusan Kepala badan Pengendali Dampak Lingkungan (Bapedal) No.8 Tahun 2000 Tentang Keterlibatan masyarakat dan keterbukaan informasi dalam proses AMDAL. Konsultasi publik ini merupakan pengumuman kepada masyarakat dan memberi kesempatan keterlibatan masyarakat. Dari laporan pelaksanaan konsultasi publik ini diperoleh masukan mengenai harapan serta kekhawatiran masyarakat.

Sosialisasi rencana penambangan pasir besi kini tidak lagi ditujukan ke kelompok warga di pesisir pantai selatan Kulon Progo, melainkan langsung ke individu, yaitu tokoh masyarakat maupun orang-orang yang memerlukan. Meski memerlukan waktu dan tenaga lebih banyak, cara ini dirasa lebih mengena karena mampu memberi pemahaman lebih komprehensif. Berdasarkan fenomena, sosialisasi secara massal sudah sulit dilakukan karena maraknya aksi penolakan.

Sosialisasi oleh Pemda Kabupaten Kulon Progo yang besinergi dengan pihak-pihak terkait antara instansi pertambangan pemda Kulon Progo dan PT JMI telah diupayakan semaksimal mungkin. Strategi bermedia maupun melalui tatap muka dan konsultasi publik telah diupayakan Humas Pemkab Kulon Progo, 
namun tetap terjadi penolakan oleh sebagian masyarakat. Penolakan oleh sebagian masyarakat ini dipengaruhi oleh berbagai faktor baik internal maupun eksternal. Faktor internal berasal dari persepsi negatif masyarakat mengenai proses penambangan yang berdampak pada kerugian terhadap lahan pertanian yang merupakan sumber mata pencaharian masyarakat. Faktor eksternal berasal dari pihak-pihak luar yang memprovokasi masyarakat agar menolak rencana penambangan pasir besi tersebut, dengan tujuan tertentu untuk kepentingan mereka, misalnya pihak-pihak yang ingin mencari peluang usaha di wilayah tersebut namun terkendala dengan adanya rencana penambangan pasir besi tersebut.

Sosialisasi terhadap rencana penambangan pasir besi tersebut sudah dilakukan oleh humas pemdasejaksebelumkontrakkarya ditandatangani maupun setelah kontrak karya ditandatangani yang dilakukan baik secara tatap muka langsung maupun melalui media baik media cetak maupun elektronik. Komunikasi secara media melalui media cetak di Koran-koran, Press release dan sebagainya. Komunikasi melalui media elektronik baik radio maupun televisi juga ada media luar ruang dengan spanduk-spanduk ataupun baliho yang dipasang di tempat-tempat stategis terutama di daerah-daerah yang mudah terlihat dan di daerah sepanjang pantai yang dihuni masyarakat

Peran humas Pemda Kulon Progo dalam kasus penambangan pasir besi di Kulon Progo adalah sebagai berikut: (1) melakukan komunikasi sosialisasi perencanaan penambangan pasir besi dengan secara tatap muka langsung dengan masyarakat sepanjang pantai dan juga sosialisasi yang dilakukan melalui media baik cetak maupun elektronik dan media luar ruang melalui baliho yang dipasang di pesisir pantai selatan; (2) berusaha membuat keseimbangan pemberitaan mengenai rencana penambangan pasir besi kepada masyarakat Kulonprogo agar masyarakat tidak terprovokasi dengan pemberitaan yang kurang tepat mengenai rencana penambangan pasir besi; (3) berusaha mencari efektifitas strategi untuk mengelola konflik penambangan pasir besi. Dengan demikian humas terus menerus mengupayakan cara-cara yang strategis baik melalui media cetak, media elektronik maupun tatap muka secara langsung kepada masyarakat; (4) badan instansi Humas dan sesama instansi di Pemda Kulonprogo saling bersinergi untuk memberikan informasi yang jelas dan benar serta langsung kepada masyarakat mengenai dampak positif penambangan pasir besi.

Dari uraian mengenai peran Humas tersebut dapat pula dikatakan bahwa Humas pemda Kulon Progo dalam menjalankan perannya sesuai dengan strategic choice theory dan power control theory. Hal ini dapat dilihat dari upaya Humas Pemda Kulon Progo dalam membangun persepsi masyarakat dan tindakan untuk membentuk lingkungan dan mengarahkan struktur serta posisi public relations dalam masyarakat. Dalam hal ini Humas berkoordinasi dengan instansi jajarannya dalam rangka mensosialisasikan dan memberikan informasi seluas-luasnya kepada masyarakat agar masyarakat memahami dan pada akhirnya menyetujui rencana yang telah diprogramkan.

Sedangkan power control Theory Humas Pemda Kulon Progo di buktikan dari kedudukannya sebagai bagian dari dari koalisi yang dominan, dalam hal ini Pemda Kulon Progo. Dengan demikian Humas mempunyai wewenang untuk memasukkan unsur tanggung jawab sosial, pemahaman publik atau komunikasi dua arah. Dengan cara ini sasaran program akan lebih dapat diadaptasikan. Namun demikian, pada kenyataan di lapangan, masyarakat masih memiliki persepsi yang keliru terhadap proses penambangan, hal ini berarti Humas Kulon Progo masih belum dapat memaksimalkan Power Control Theory, karena belum dapat menjalankan kedudukannya sebagai bagian dari koalisi yang dominan.

Sebagai corong Pemda, Humas Kulon Progo harus bisa menyakinkan masyarakat bahwa apa yang disampaikannya itu valid, akurat dan menjadi bagian dari kebijakan atau program organisasinya. Memaksimalkan peran Humas 
dapat juga dilakukan melalui media. Humas harus bisa memerankan dirinya sebagai penyampai informasi yang memiliki penguasaan atas materi yang disajikan kepada media yang merupakan salah satu stakeholder-nya, juga harus mampu memberikan jawaban acapkali ada pertanyaan dari masyarakat yang dihadapinya terakhir adalah kemampuan membangun interaksi dengan berbagai pihak, karena itu merupakan entry point menuju kerja kehumasan yang profesional.

Humas di pemerintahan menjadi pemberi informan kepada masyarakat sekaligus penghubung antara pemerintah dan masyarakat. Hal ini bisa dipahami karena pemerintah adalah agen dari masyarakat itu sendiri. Masyarakat memberikan haknya untuk diwakilkan kepada orang-orang pemerintahan agar bisa diselenggarakan dengan sebaik-baiknya. Maka suatu kewajaran apabila pemerintah harus tetap terhubung dengan masyarakat. Humas menjadi palang pintu bagi hubungan yang harmonis antara pemerintah dengan publik atau masyarakat. Dalam hal sosialisasi renacana penambangan pasir besi di Kulon Progo Humas Pemda harus berhasil menjalin komunikasi yang efektif dengan masyarakat agar persepsi keliru masyarakat mengenai kegiatan penambangan yang telah terlanjur terbentuk dapat diperbaiki. Agar sosialisasi dapat berjalan dengan baik sesuai yang diharapkan, Humas hendaknya mengingatkan beberapa hal. Pertama, humas adalah pemberi informan dengan mengedepankan komunikasi dua arah bukan hanya sebagai juru bicara namun juga mampu membawa nuansa demokratis, diskusi dan tukar pikiran untuk perbaikan organisasi. Kedua, mengingat peran humas pemerintah lebih sebagai informan maka kerjasama dan koordinasi dengan pelaksana dan pejabat teknis pemerintah perlu lebih ditingkatkan untuk mencapai hasil yang diinginkan. Dalam hal ini untuk menjaga hubungan internal seorang humas juga harus memperhatikan kemampuan verbalnya. Berhasil tidaknya suatu komunikasi sangat dipengaruhi oleh kemampuan dalam menyampaikan ide dan maksud yang ada.
Rencana penambangan pasir besi menimbulkan pro dan kontra pada masyarakat bahkan sudah mengarah ke konflik yang tentu saja merugikan semua pihak. Masyarakat mengkhawatirkan pengelolaan penambangan pasir besi tidak membawa manfaat sebagaimana diharapkan, karena masyarakat tidak mengetahui secara pasti apakah dalam pengelolaan itu memang betul-betul baik seperti apa yang direncanakan dan disosialisasikan sebelumnya.

Persepsi keliru masyarakat inilah yang menjadi hambatan dalam sosialisasi Humas Kulon Progo dalam merealisasikan rencana penambangan pasir besi. pantai selatan. Masyarakat menganggap semua kegiatan yang berhubungan dengan pertambangan itu merusak lingkungan dan menggusur lahan pertanian pesisir pantai selatan. Sehingga masyarakat bersikeras menolak rencana penambangan pasir besi meskipun humas Pemda beserta instansi jajarannya sudah berupaya memberi penyuluhan mengenai proses penambangan melalui berbagai kegiatan sosialisasi antara lain konsultasi publik.

Persepsi keliru masyarakat yang kontra dengan proses penambangan ini menghambat sosialisasi pemda Kulon Progo karena masyarakat sudah tidak mempunyai kepercayaan dan keyakinan terhadap segala bentuk sosialisasi yang telah dilakukan oleh Humas Pemda Kulon Progo beserta instansi yang terkait dalam rencana penambangan pasir besi tersebut. Oleh karena itu, penolakan terhadap rencana penambangan pasir besi Kulon Progo masih terjadi meskipun humas pemda Kulon Progo telah berusaha melakukan sosialisasi dan berusaha memberikan wawasan pada masyarakat mengenai proses penambangan yang bermanfaat dan tidak merusak lingkungan atau merugikan terhadap mata pencaharian warga masyarakat sekitar lokasi penambangan. Berdasarkan uraian di atas maka diketahui bahwa dalam menjalankan perannya, Humas Pemda Kulon Progo menemui hambatan-hambatan yakni pertama, hambatan internal berupa belum maksimalnya fungsi humas yang berkedudukan 
sebagai koalisi yang dominan yang terkait dengan wewenangnya untuk memasukkan unsur tanggung jawab sosial, pemahaman publik atau komunikasi dua arah, kedua, hambatan eksternal berupa persepsi masyarakat yang keliru mengenai proses penambangan merusak lingkungan.

\section{Simpulan}

Disimpulkan bahwa peran humas Pemerintah daerah Kabupaten Kulon Progo dalam menghadapi masalah penambangan pasir besi di Kulon Progo adalah sebagai berikut : (1) melakukan komunikasi sosialisasi perencanaan penambangan pasir besi dengan secara tatap muka langsung dengan masyarakat sepanjang pantai dan juga sosialisasi yang dilakukan melalui media baik cetak, elektronik maupun media luar ruang melalui baliho yang dipasang di pesisir pantai selatan; (2) berusaha membuat keseimbangan pemberitaan mengenai rencana penambangan pasir besi kepada masyarakat Kulonprogo agar masyarakat tidak terprovokasi dengan pemberitaan yang kurang tepat mengenai rencana penambangan pasir besi; (3) berusaha mencari efektifitas strategi untuk mengelola konflik penambangan pasir besi. Dengan demikian humas terus menerus mengupayakan cara-cara yang strategis baik melalui media cetak, media elektronik maupun tatap muka secara langsung kepada masyarakat; (4) badan instansi Humas dan sesama instansi di Pemda Kulonprogo saling bersinergi untuk memberikan informasi yang jelas dan benar serta langsung kepada masyarakat mengenai dampak positif penambangan pasir besi.
Adapun hambatan yang dihadapai Humas Pemda Kulonprogo dalam menghadapi masalah penambangan pasir besi di Kulonprogo adalah persepsi keliru masyarakat pesisir pantai selatan terhadap proses penambangan karena berpikir semua kegiatan yang berhubungan dengan pertambangan itu merusak lingkungan dan menggusur lahan pertanian pesisir pantai selatan. Sehingga masyarakat bersikeras menolak rencana penambangan pasir besi meskipun humas Pemda beserta instansi jajarannya sudah berupaya memberi penyuluhan mengenai proses penambangan melalui berbagai kegiatan sosialisasi antara lain konsultasi public.

\section{Daftar Pustaka}

Abdurrachman,Oemi.(2001).Dasar-dasarPublic Relations. Bandung: Citra Aditya Bakti. Islah, T. (2010). Kajian Pasar Mineral Dan Usulan Strategi Eksplorasi. Bandung: Laporan Pusat Sumber Daya Geologi. Kurniasari, Atika, Puji Lestari, dan Isbandi. (2008). Strategi Marketing Public Relations PT. Telkom Kancatel Pati dalam Program "Flexi Door to Door" dan "Speedy Go to School" untuk Membangun Brand Awareness dan Brand Knowledge" di Wilayah Pati. Jurnal Ilmu Komunikasi, 6(3), 228-241.

Moleong Lexy J. (2007). Metodologi Penelitian Kualitatif. Bandung: Remaja Rosdakarya. Rahardjo, M. (2010). Research Repository Universitas Islam Negeri Maulana Malik Ibrahim. Retrieved from Research Repository Universitas Islam Negeri Maulana Malik Ibrahim: http://repository.uin-malang.ac.id/1133/

Usman, Husaini \& Purnomo Setiady Akbar. (2009). Metodelogi Penelitian Sosial. Jakarta: Bumi Aksara 